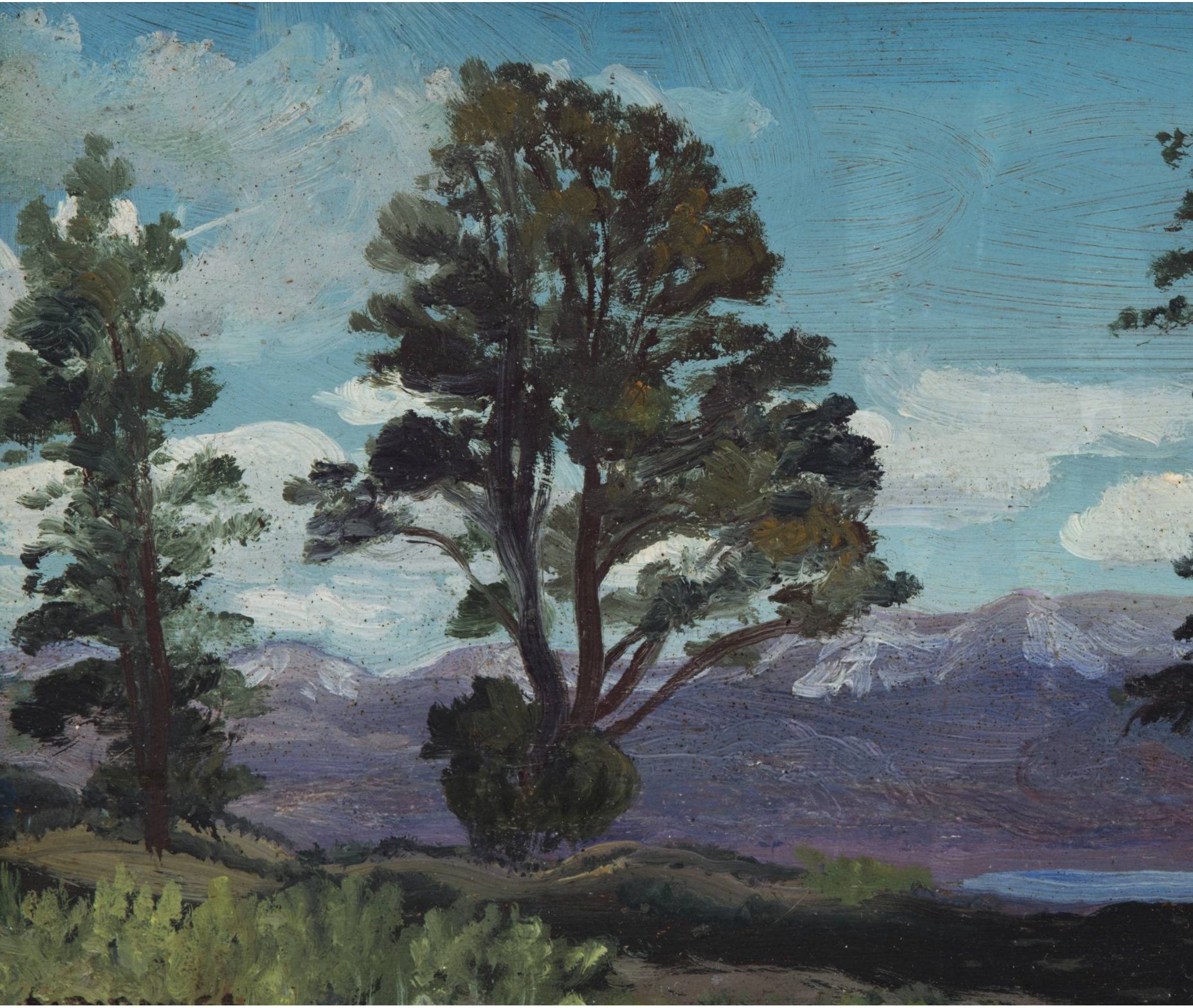

Arthur B. Davies, Twin Lakes, Colorado, 1905.

Oil on panel, $51 / 4 \times 93 \frac{3}{8}$ in. Private collection 


\section{Discovering Davies-Land}

\section{Arthur B. Davies in the West 1905}

\section{Charles C. Eldredge}

In June 1905 Arthur B. Davies left New York City on a trip that had great consequence for his career. The artist was riding high on the recent success of not one but two solo shows-an exhibition at the prominent Doll \& Richards Gallery, in Boston, and subsequently one with his New York dealer, William Macbeth. The proceeds from sales of his popular paintings were sufficient to underwrite the summer excursion on which he was embarking. Escapes from the discomforts of summer in the city were not unusual; artists for generations had been trekking to scenic vistas and salubrious climes, seeking seasonal inspiration for their winter's work back in the urban studio. Since establishing himself in New York in 1888, Davies had joined this exodus on several occasions. Although he married in 1892 and had children shortly thereafter, Davies continued to enjoy periodic sojourns away from home, with a particular preference for Europe, the favored destination for many artists of his era. In the summer of 1895 he visited Amsterdam, Paris, and London; in 1897, Ireland, Belgium, Germany, Italy, and Spain; in 1901, London again. But in the summer of 1905-a year headlined in one magazine as the dawn of "Another 'Go West' Period"-this dedicated Europhile turned in a different direction. ${ }^{1}$ 
It was as if Davies were heeding the advice of Henry David Thoreau, whose famous essay "Walking" was published in June 1862, a month after the author's death and just three months before Davies's birth. "When I go out of the house for a walk," Thoreau wrote, "uncertain as yet whither I will bend my steps . . . I finally and inevitably settle southwest. . . . Eastward I go only by force; but westward I go free. ... We go eastward to realize history and study the works of art and literature, retracing the steps of the race; we go westward as into the future." The philosopher concluded that "I must walk toward Oregon, and not toward Europe."2

When Davies left home late in the spring of 1905, there was no uncertainty about his direction or his destination. This trip was undertaken to visit the Lewis and Clark Centennial Exposition in Portland, one of the numerous celebrations of history, place, and modernity that punctuated the decades before World War I. ${ }^{3}$ Seven of Davies's paintings were included in the Department of Fine Arts Exhibition at the Portland fair, six of them loaned by William Macbeth. These works, which ranged in date over nearly a decade, were imaginative compositions of the sort that had earned Davies early notice-subjects from ancient mythology and scenes from his far-flung foreign travels. ${ }^{4}$

In the West adventure also beckoned. For decades landscapists had sought scenic inspiration in the field. "Pleinairists received constant encouragement from the press," according to the landscape scholar Eleanor Jones Harvey; one mid-nineteenthcentury art journal declared that "the true artist ... will risk body and brains in his pursuit of a good sketch."5 So attractive became these pursuits away from home and studio that Henry Tuckerman, in his 1867 chronicle of American artists, praised painting from nature as "an element in American artist-life which gives it singular zest and interest." As it had for many before Davies, the prospect of adventureas well as an escape from the city and domestic routine-added to the West's allure for him.

Transcontinental rail travel in 1905, though vastly improved in speed and comfort from earlier generations, was still a long and arduous undertaking. From Chicago, where Davies and his family had lived when he was a teenager and to which he had likely journeyed by rail, the artist probably continued to Denver on the Atchison, Topeka \& Santa Fe (AT\&SF), the railroad for which, in 1881-82, he had worked as a draftsman in New Mexico Territory, planning new rail lines in the Southwest. On that occasion, which was his only previous experience in the American West, Davies was still early in his career, and he was limning the land with a practical purpose, not the personal expression of his later paintings. However, as he later admitted, "That training [as draftsman for AT\&SF] made me see and feel not the surface only of those mountains, but their construction, as one feels the anatomical structure of the human figure when expressing its exterior forms." 7

Davies's early experience in the Southwest inspired a lifelong fascination with mountainous landscapes. In 1898, after his first visit to the Great Smoky Mountains in western North Carolina, the artist wrote with excitement to Macbeth, describing

one of the most enjoyable trips ... to the top of Junaluska mountain ... I have been much surprised at variety in these many peaks and I feel it is like a new language which I must become familiar with. I have been making innumerable notes... I have several good motifs. . . the mountains are an inspiration. 8 
But not Junaluska, nor even the peaks of New Mexico or the Mexican highlands, could compare with the grandeur of the Colorado Rockies. Heading west from Denver on the Denver \& Rio Grande Railroad, Davies encountered scenery and summits unrivaled in his earlier travels. The pace slowed as Davies took advantage of opportunities for art and recreation along the way. At Twin Lakes, near Leadville, in Colorado's high country, he was distracted by the vista- and by trout. In mid-June he reported excitedly to Macbeth about "my week just finished at Twin Lakes fishing \& sketching!!! I resemble a carcass left in the sun, fat and blistered. . . . I caught a few trout and had a good, new experience." Lying between Mount Elbert and Mount Massive, two of Colorado's highest peaks, Twin Lakes provided a welcome respite and artistic inspiration; "a most beautiful place," Davies concluded. "I doubt if I shall find anything better." 9

In a quick oil sketch Davies recorded the view, framed by slender pines, across the water to the distant mountains (frontispiece). Painted on diminutive wooden panels, these easily transported souvenirs of his western travels were intended as inspiration for easel paintings to be made after his return to New York. From Seattle in late September, nearing the end of his journey, Davies dispatched a parcel of approximately seventy such sketches to Macbeth, along with a message urging care in their handling since some were so fresh that the paint was not yet fully dry. ${ }^{10}$

When exhibited in New York shortly after his return, Davies's "superbly faithful and glowing sketches" won critical praise and the prediction that "some day collectors will compete for them." 11 Yet surprisingly, although the easel paintings they inspired have been admired and recognized as pivotal in the artist's career, his oil sketches from the West have been largely neglected. Nevertheless, today a number of these quickly brushed notations of scenery glimpsed in passing remain, and the best of them are still "glowing."

Davies's reputation today rests on his figurative works, particularly those featuring the female nude, as well as his participation in the 1908 exhibition of The Eight, painters who challenged the conservative standards of the National Academy of Design, many of them (but not Davies) with gritty urban subjects dashingly rendered. Even more so, contemporary scholars recognize Davies for his role as an advocate for modern art, most notably as president of the Association of American Painters and Sculptors, organizers of the famed Armory Show in 1913. At the time of his western sojourn, however, all that still lay ahead.

Arresting alpine motifs abounded in the Rockies. As spring arrived in Colorado's high country, so did the artist. He found during the ride from Twin Lakes to Leadville that "in the stimulating air was something to spiritualize in paint."12 However, Leadville itself he found less inspiring, a bleak shanty town populated by "knots of miners and prospectors" who would not hold him long. From there Davies headed toward the San Juan country of southwestern Colorado. On June 18 he announced in a letter to Macbeth his intention to be in Ouray the next day and, rejuvenated by his Twin Lakes sojourn, reassured the dealer, "I am feeling tip-top."13 Between Leadville and Ouray, however, there were plenty of scenic distractions, a number of them warranting stops for sketches, and Davies's progress began to slow.

At Emerald Lake, in the present-day San Juan National Forest, the artist paused to make several sketches of the lake and mountains. In one wide-angle view (fig. 1), dark mountain slopes frame a distant, purple peak and placid water in the foreground, its surface defined by a narrow, pale stroke of paint that snaps 

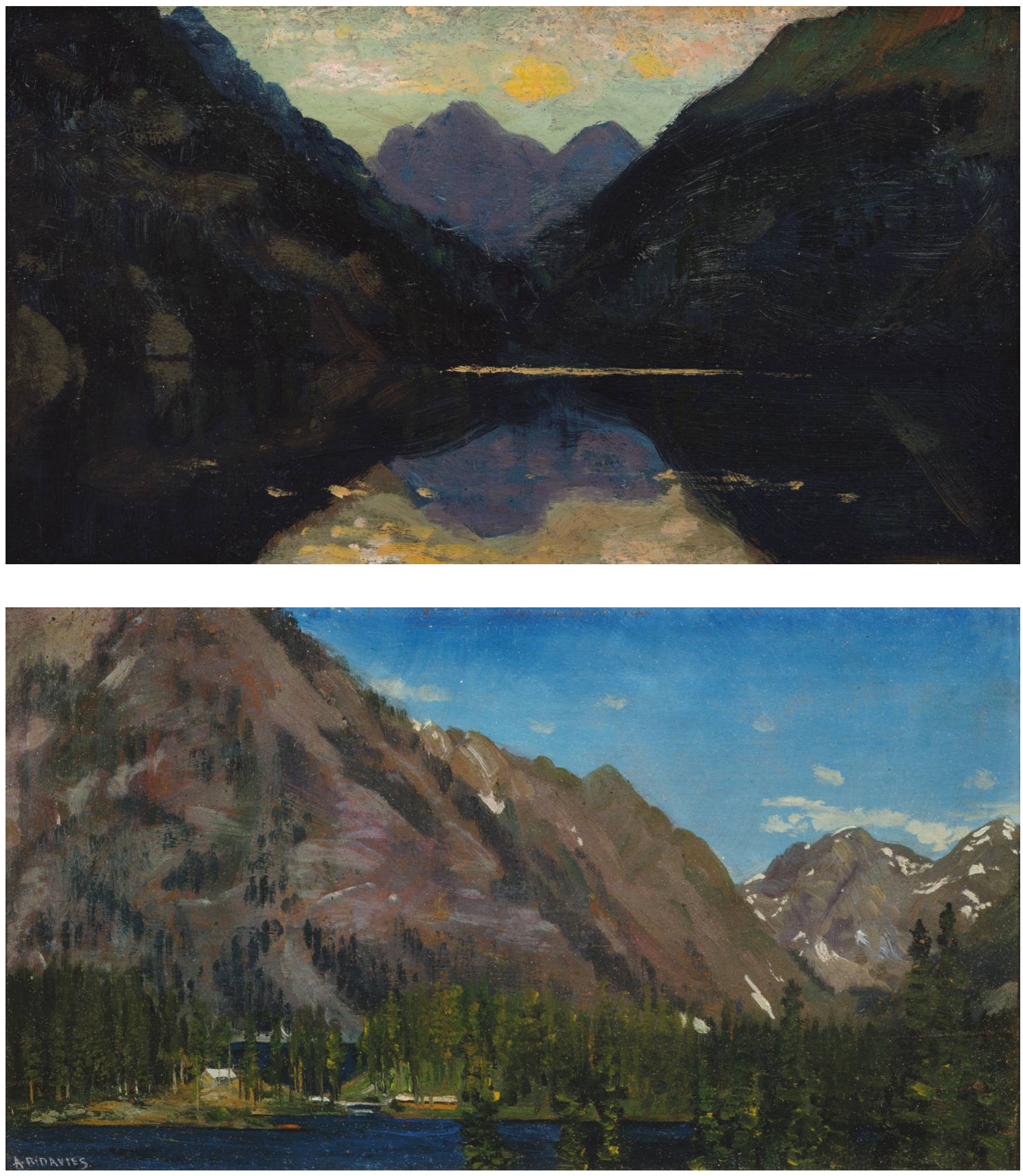


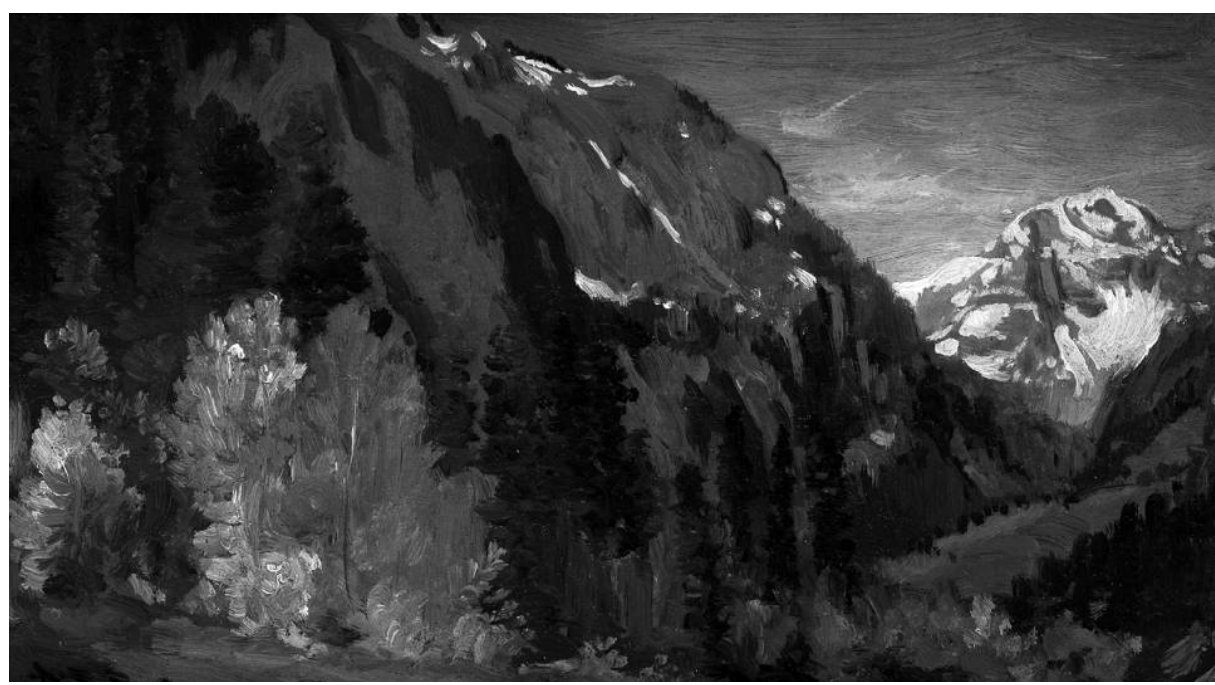

the picture into focus. The slopes and peak in turn are mirrored in the lake's surface, creating a symmetrical design of four intersecting $\mathrm{V}$-shaped planes. In another sketch of Emerald Lake (fig. 2) the mountain rises more abruptly, blocking the view, not framing it; its dark flank presses against the shoreline as it looms over several buildings that suggest the beginnings of settlement, or perhaps vacationers' accommodations. While Davies's intent was not narrowly topographic or documentary, the inclusion of buildings in the landscape was unusual for him;

1 Arthur B. Davies, Emerald Lake, 1905. Oil on panel, $5^{1 / 4} \times 9^{1 / 2}$ in. Private collection

2 Arthur B. Davies, Emerald Lake, Colorado, 1905. Oil on panel, 63/8 x 101/2 in. Denver Art Museum Collection, D.A.M. Yankees and funds from the Acquisition Challenge Grant, 1987.16. Photo courtesy of the Denver Art Museum

3 Arthur B. Davies, Ouray, Colorado, 1905. Oil on panel, $51 / 4 \times 91 / 2$ in. Private collection the painting is less moody, less mystical than other sketches and their successors from the easel. This effect apparently pleased the artist, whose signature on the front of the painting is unusually prominent. (More often he signed the panel in pencil on the verso.)

Between Emerald Lake and Ouray, near Ironton, the artist's attention was caught by the landscape tinted rust-red by iron oxides in the soil. Red Mountain, Ironton (ex-Spanierman Gallery) records the dramatic vista and suggests Davies's facility with color. The foreground is dominated by earthen tones and dark greens, some nearly black, colors found in many of his early works. In the middle distance, a slope of warm iron-red strikes a colorful note. Red mountain, white clouds, and blue sky suggest a national palette suitable for an American landscape.

The artist's progress was slowed by scenic distractions, but eventually the rails crossed the Red Mountain Pass, cresting at 11,000 feet, and descended to Ouray. The old mining town is nestled at the head of a narrow valley, surrounded by the lofty San Juan Mountains, some of the highest and most rugged peaks in the Rockies. Davies recorded their steep rise and snowcapped summits in a quick sketch (fig. 3), repeating the asymmetrical composition of his earlier view at Emerald Lake, but he did not include any buildings. At the time of Davies's visit the town was prospering, thanks to its gold and silver mines, and several hotels served a fledgling tourist trade. "Trains are terribly crowded," Davies reported, presumably including vacationers. ${ }^{14}$ But it was natural scenery, not evidence of progress, that most often caught the artist's attention.

From Ouray the Denver \& Rio Grande line ran northwestward, down Colorado's Western Slope toward Utah. From Leadville, Davies anticipated arriving in Salt Lake City about July 1 . Given the vagaries of travel and the distractions of scenery, however, he did not get to the city until July 17 . He wrote the next day to Macbeth, explaining that the delay meant "I shall give up the Yellowstone trip which will consume seven days . . \& \& my Lake Tahoe would be cut out practically for sketching purposes." He reported that "Salt Lake is a great little city; you must not miss it." Nonetheless, Davies's stay there was brief, only long enough to dispatch a shipment of "spoiled" panels back to New York and to retrieve a batch of replacements that Macbeth had sent. "These new ones I shall save for lucky hits in the Northwest." In Colorado he had "seen enough already to satisfy any ordinary man," and now "[T]he great Pacific calls." So, "It's off to Lake Tahoe tomorrow."15

Davies left Salt Lake City on July 19 and the next morning arrived at Truckee, California, the entry to scenic Tahoe country. He planned to spend a week there before 

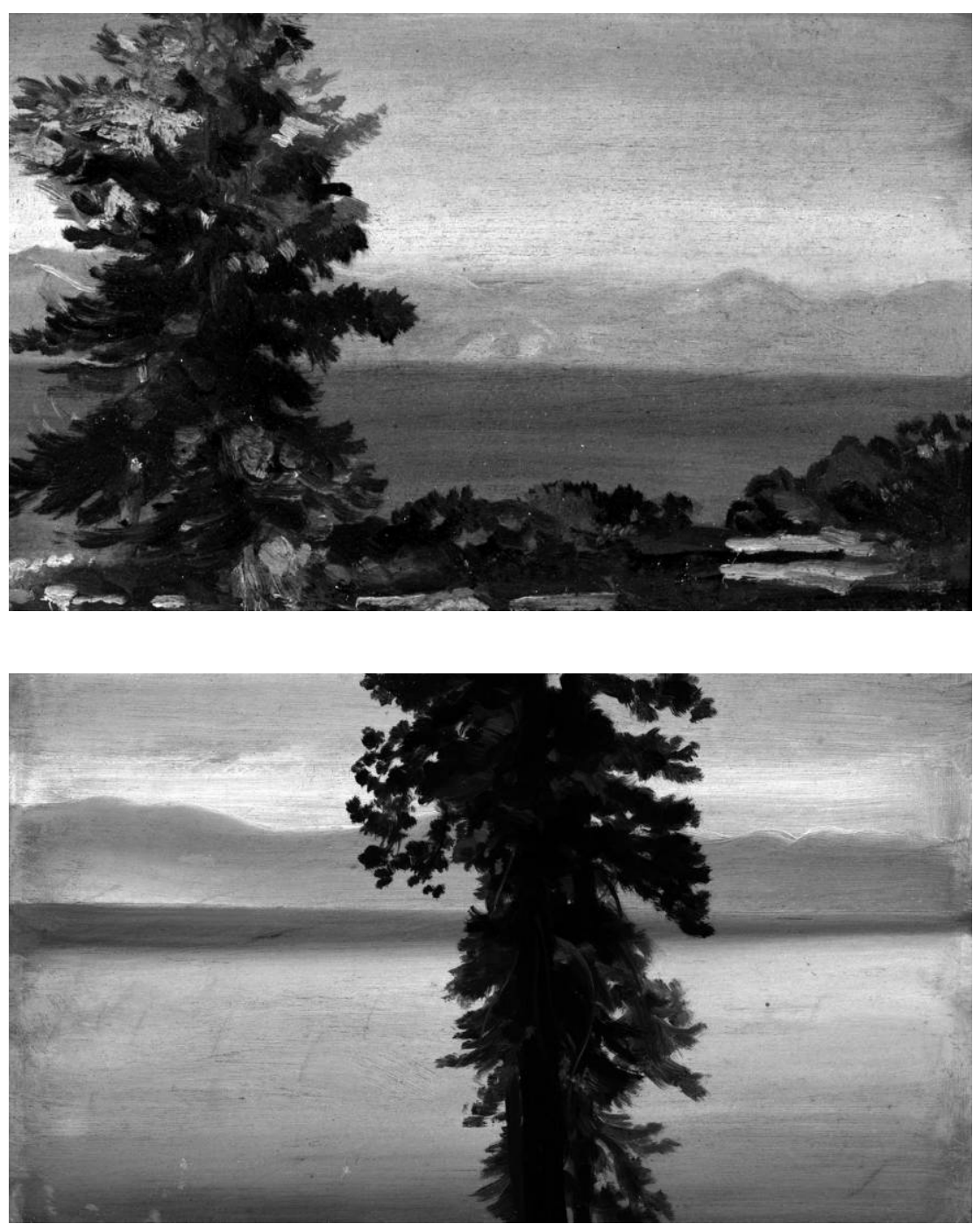

moving on to San Francisco; judging from the multiple panels that survive, it was time well spent. At Emerald Bay, on the lake's southwest margin, he sketched the view across the water to the far shoreline and the mountain beyond (Oakland Museum of California), a composition similar to that he had employed at Emerald Lake in Colorado (see fig. 2). A second view of the Tahoe motif (ex-Garzoli Gallery) included a pine bough at the left margin, a bit of foreground greenery contrasting with the vaporous landforms in the distance. The composition apparently satisfied him, for he repeated it with an entire tree, not just a bough, punctuating the left side of another view (fig. 4). Sketches like these served later as the inspiration for easel paintings of the site, such as Lake and Island, Sierra Nevada (1905, ex-coll. Art Institute of Chicago), depicting Tahoe's only island, Fannette, in the middle of Emerald Bay.

The asymmetrical design of Davies's views of the area is most effective in another sketch, Lake Tahoe (fig. 5). In it a foreground tree arrests attention, placed before simplified, smoothly brushed bands of blue and mauve that depict a watery middle plane and the far shore. The effect here is akin to woodblock prints by Hokusai and other Japanese masters, no surprise, for Davies shared enthusiasm for Japanese prints with numerous others

4 Arthur B. Davies, Lake Tahoe, 1905. Oil on panel, $5 \frac{1}{2} \times 93 / 8$ in. Courtesy of Joel B. Garzoli Fine Art, San Francisco, Calif.

5 Arthur B. Davies, Lake Tahoe, ca. 1905 . Oil on wood, $53 / 8 \mathrm{x}$ $93 / 8$ in. Collection of the Oakland Museum of California, Gift of Concours d'Antiques, Art Guild of his generation. Bennard Perlman, one of Davies's biographers, noted additionally that some of the artist's later and larger easel paintings of California scenes demonstrate the mathematical principle of the Golden Section - the ratio of small part to larger as larger is to whole (3:5::5:8) - a compositional approach that accounts for the off-center placement of a prominent tree or peak approximately fifteen inches from one side of several landscapes. ${ }^{16}$ Whether from nineteenth-century Japanese prints, the ancients' principle of the Golden Section, or simply from the serendipitous discovery of tree and vantage, the designs had their initial impetus on the shores of Lake Tahoe.

Venturing south, Davies continued to the Tuolumne region. His travels might have been inspired by a contemporary account that appeared in the popular press on the eve of his departure from New York. "[T] o see California understandingly," the author advised, "one must visit the mountains as well as the valleys. Probably no other section is richer in scenes noted for their beauty and grandeur, places made famous in literature than is Tuolumne county in the Sierra Nevada foothills of California."17 Davies's destination was Yosemite National Park, which had been established by an act of Congress on October 1, 1890. In August and September of that year, John Muir, the great champion of Yosemite whose advocacy led to the federal designation, described to distant readers of the popular 
6 Arthur B. Davies, Half Dome from Glacier Point, 1905. Oil on wood panel, $51 / 4 \times$ x $1 \frac{1}{2}$ in. Private collection of Michael P. and Patricia A. Smith. Photo courtesy of James D. Julia Auctioneers, Fairfield, Maine, U.S.A., www.jamesdjulia.com

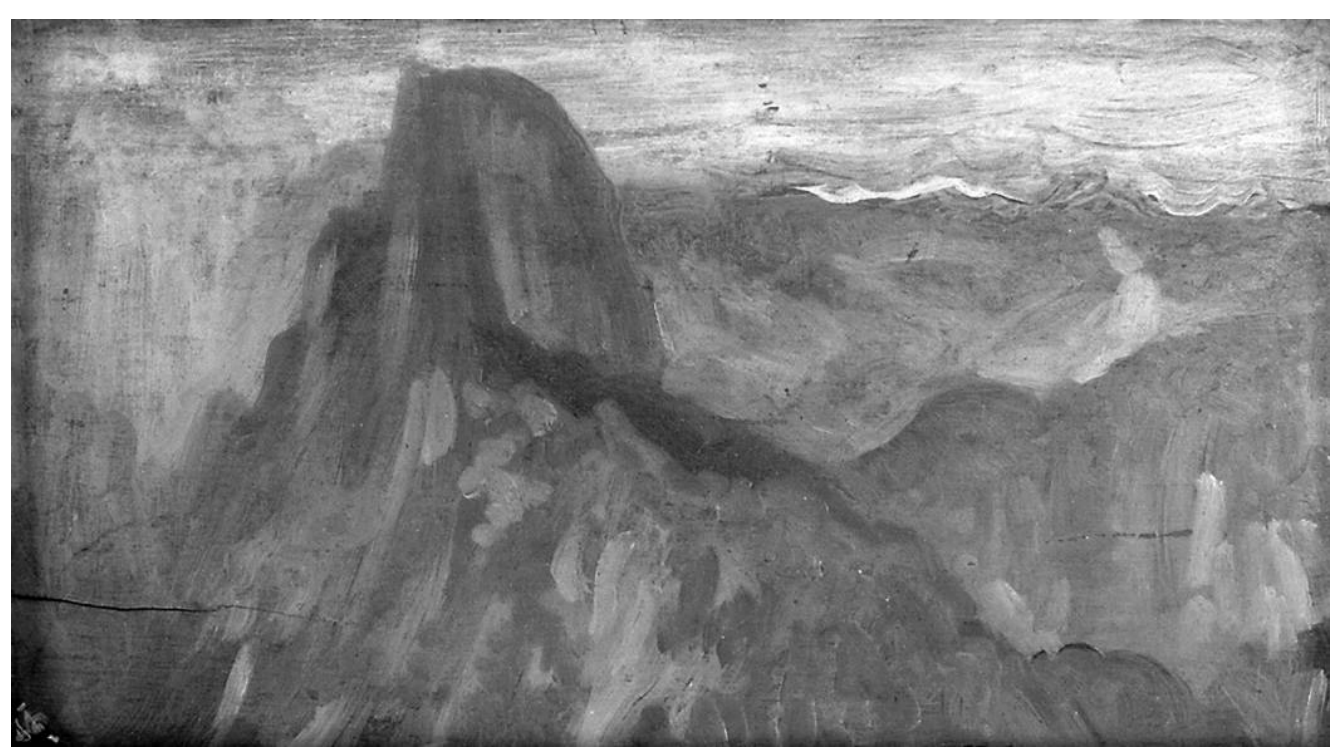

Century Magazine the treasures of the region and the features of the proposed national park. ${ }^{18}$ Muir's celebration of this beauty spot was accompanied by black-and-white illustrations by artists ranging from the notable, like Thomas Moran, to the anonymous. Several of them were initialed "ABD," an indication that they were early examples from Davies's hand. His early illustrations of Cathedral Peak, the Merced River, and the entrance to the Hetch Hetchy Valley were drawn from photographs or verbal accounts by others, or from his imagination, for the Sierra were as yet unvisited by him. Now, fifteen years later, Davies had his first opportunity to experience the wonders that Muir extolled.

The mountains' precipitous rise from the valley floor added drama to the numerous depictions of the park that appeared in the late nineteenth century. Thomas Hill, the most frequent and prolific painter of the Yosemite region, repeatedly depicted such attractions as Half Dome, Bridal Veil Falls, and the grand, long view of the valley. At the time of Davies's visit, the elderly Hill (1829-1908), who had been working with the Sierra landscape for nearly half a century, was residing in the park at the Wawona Hotel and continuing to portray Yosemite's glories. His canvases were eagerly sought by wellheeled visitors, as by his brush Hill helped make the park's chief sites familiar.

Like many other tourists-including President Theodore Roosevelt, whose 1903 visit with his friend Muir was well documented and added to the park's allure-Davies was drawn to such familiar views. He sketched, for instance, Cathedral Peak, Tuolumne Meadows (Joel B. Garzoli Fine Art, San Francisco) as well as Half Dome from Glacier Point (fig. 6), one of the most popular views in the park (and a site where the president and Muir had been photographed). In each case Davies composed the painting with the highest point off center, just as he had asymmetrically arranged pines before views of Lake Tahoe. The trees of Yosemite, however, inspired a different composition. Instead of his customary horizontal views, Davies, surrounded by lofty sequoias, turned his panel 90 degrees to produce a vertical composition, its elongation echoing the rise of the ancient evergreens, as in Trees, Mariposa Grove (ex-Spanierman Gallery). Such sketches became sources for Davies's later studio paintings, in which compositions often featured similar tree trunks—arboreal monuments that, as later described by Marsden Hartley, "become columns of Doric eloquence and simplicity."19

From Yosemite the artist made his way westward to the mid-California coast, where he received a warm welcome from the congenial community of artists, writers, and 

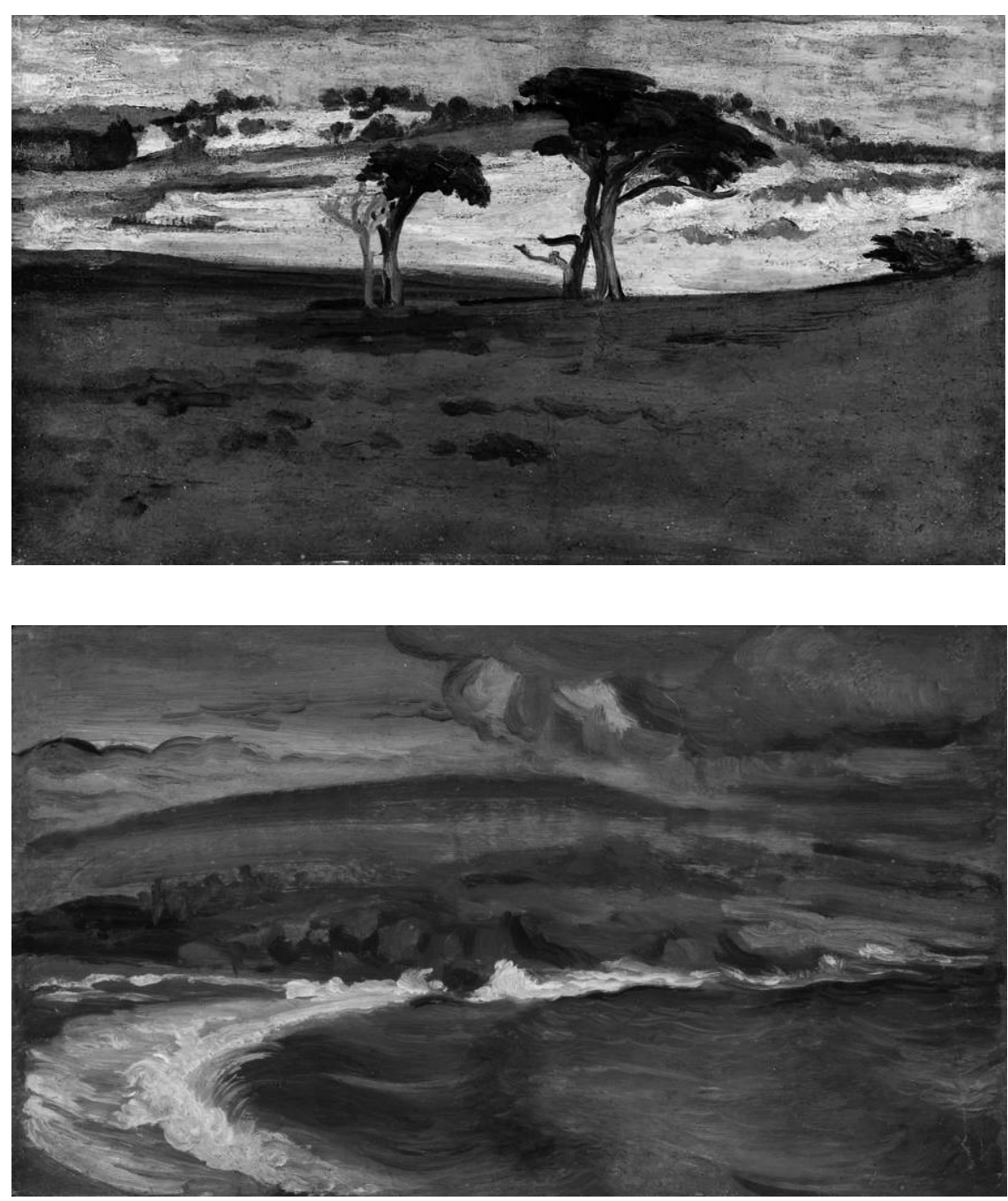

freethinkers gathering in scenic Carmel and Monterey. Many years later the widow of one Bay Area artist recalled spirited times in that creative enclave: "We'd get a telegram from [the Monterey painter Charles] Rollo Peters, 'So and so from New York's going to be here, bring your wife and two or three pictures.' So we would stay with them for two or three days while he gave a big party and sold pictures." 20

In addition to the pleasant company, Davies discovered landscape attractions of the sort described by the local author Mary Hunter Austin. About the same time as Davies, she had been drawn to the region by "the Mission buildings, the strange wild beach at Carmel, the matted plots of cedar, the dunes all white and silvery, the glittering chaparral."21 Davies made obligatory visits to such historic missions as San Juan Bautista, whose facade provided the inspiration for several pencil sketches. ${ }^{22}$ More often, however, he painted the landscape without evidence of human settlement. In Monterey arboreal subjects again attracted Davies's attention-not the venerable giants of Yosemite but the oaks and cypresses that punctuated the rolling landscape. In Live Oaks, Monterey (1905, ex-Garzoli Gallery), the trees mass together, as they often do
7 Arthur B. Davies, Landscape, Monterey, California, ca. 1905. Oil on panel, 55/16 x 913/16 in. Image courtesy of Los Angeles County Museum of Art

8 Arthur B. Davies, California Bay, n.d. Oil on panel, $5 \mathrm{x}$ 9 in. Brigham Young University Museum of Art, Purchase/gift from the Mahonri M. Young Estate, 1959 in the sheltered valleys beyond the coast; in other sketches, such as Landscape, Monterey, California (fig. 7), a single cypress, or several, are bent by sea winds. The coast also captured the artist's attention. In some sketches the Pacific crashes against rocky Monterey headlands, while in others it washes ashore in a foamy arc, as in California Bay (fig. 8), perhaps a view of Carmel's Monastery Beach.

Farther north, in San Francisco, William Macbeth had provided Davies with introductions to the gallerist's West Coast counterparts. Prominent among them was the firm Vickery, Atkins \& Torrey, purveyors of fine furniture (European and Japanese) and decorative objects to embellish the new homes and gardens of Bay Area barons. In their downtown showrooms the dealers also exhibited and sold works of art, including Japanese prints, watercolors, and oil paintings, the last chiefly landscapes of a tonalist sort (e.g., Barbizon School, late George Inness, William Keith). ${ }^{23}$ According to one source, it was Frederick C. Torrey, a partner in the firm, who hosted Davies in the city. ${ }^{24}$

While in San Francisco Davies sketched the view looking north from Twin Peaks across the city and its Golden Gate Park (fig. 9). The painting is unusual for its urban subject, one seldom encountered in Davies's western scenes. It is exceptional as well for its provenance, being a gift from Davies to a fellow artist, Xavier Martinez. ${ }^{25}$ The gift suggests the friendship that developed between the visitor and Martinez, one of the young leaders in the 


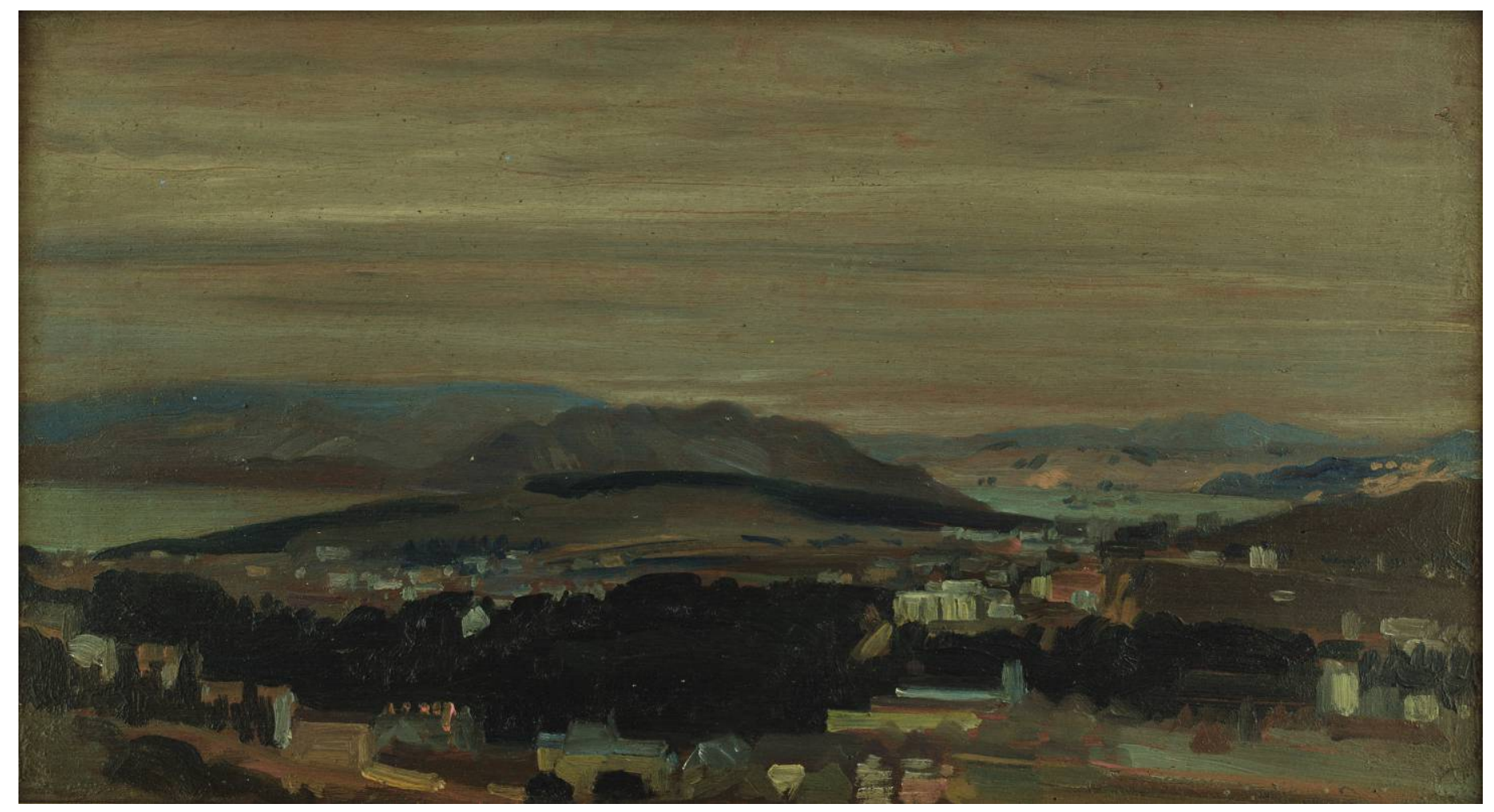

9 Arthur B. Davies, View of San Francisco, 1905. Oil on wood, $5 \frac{1}{1 / 8} \times 93 \frac{3}{8}$ in. Collection of the Oakland Museum of California, Gift of Mr. and Mrs. Robert Leefeldt resident art community who had welcomed Davies to San Francisco. That the two should meet was no coincidence. San Francisco's Sequoia Club held an exhibition of Martinez's work in the summer of 1905, coincident with Davies's visit to the city; he also showed that year with the California Society of Artists, the group of young Turks that Martinez helped found in 1902 in a revolt against the conservative standards that prevailed in California. At the time of Davies's visit, Martinez was preparing for a fall exhibition at the Vickery, Atkins \& Torrey gallery, featuring a group of works produced on a recent trip to his native Mexico, as well as local landscapes and scenes of Paris. That exhibition was restaged the following year in New York by Macbeth, suggesting commercial as well as artistic ties between the two artists. ${ }^{26}$

The gregarious and affable Martinez provided a center for San Francisco's bohemian cultural life. He hosted open-house receptions every Sunday, with guests drawn from the area's creative avant-garde, among them the novelist Jack London. Davies commissioned Martinez to paint London's portrait, part of a suite of six likenesses of prominent westerners intended for an exhibition in the East. ${ }^{27}$ Martinez was a member of San Francisco's Bohemian Club, a gathering of the city's corporate leaders and creative select. At least one Davies sketch, Bohemian Grove (private collection), depicts the Northern California forest retreat where members of the Bohemian Club still come together in fraternal gatherings; Davies was doubtless a guest of Martinez at the grove, perhaps even at such an assembly, and the sketch is a further memento of their friendship.

Following the calamitous San Francisco earthquake in April 1906, which destroyed his studio, Martinez relocated to the East Bay. His new home-studio in Piedmont was built largely by the artist himself, with some materials supplied by friends - and with a generous contribution of $\$ 300$ from Davies (approximately $\$ 8,000$ today). Many years later Martinez's widow recalled in simple yet moving terms the gift that was made "to help a fellow artist."28 
10 Arthur B. Davies, North from Mt. Tamalpais, ca. 1905. Oil on wood, $51 / 4 \times 93 / 8$ in. Collection of the Oakland Museum of California, Gift of Concours d'Antiques, Art Guild

11 Arthur B. Davies, Pacific Parnassus, Mount Tamalpais, ca. 1905 . Oil on canvas, $261 / 4 \mathrm{x}$ $401 \frac{1}{4}$ in. Fine Arts Museums of San Francisco, Museum purchase, Gift of The Museum Society Auxiliary
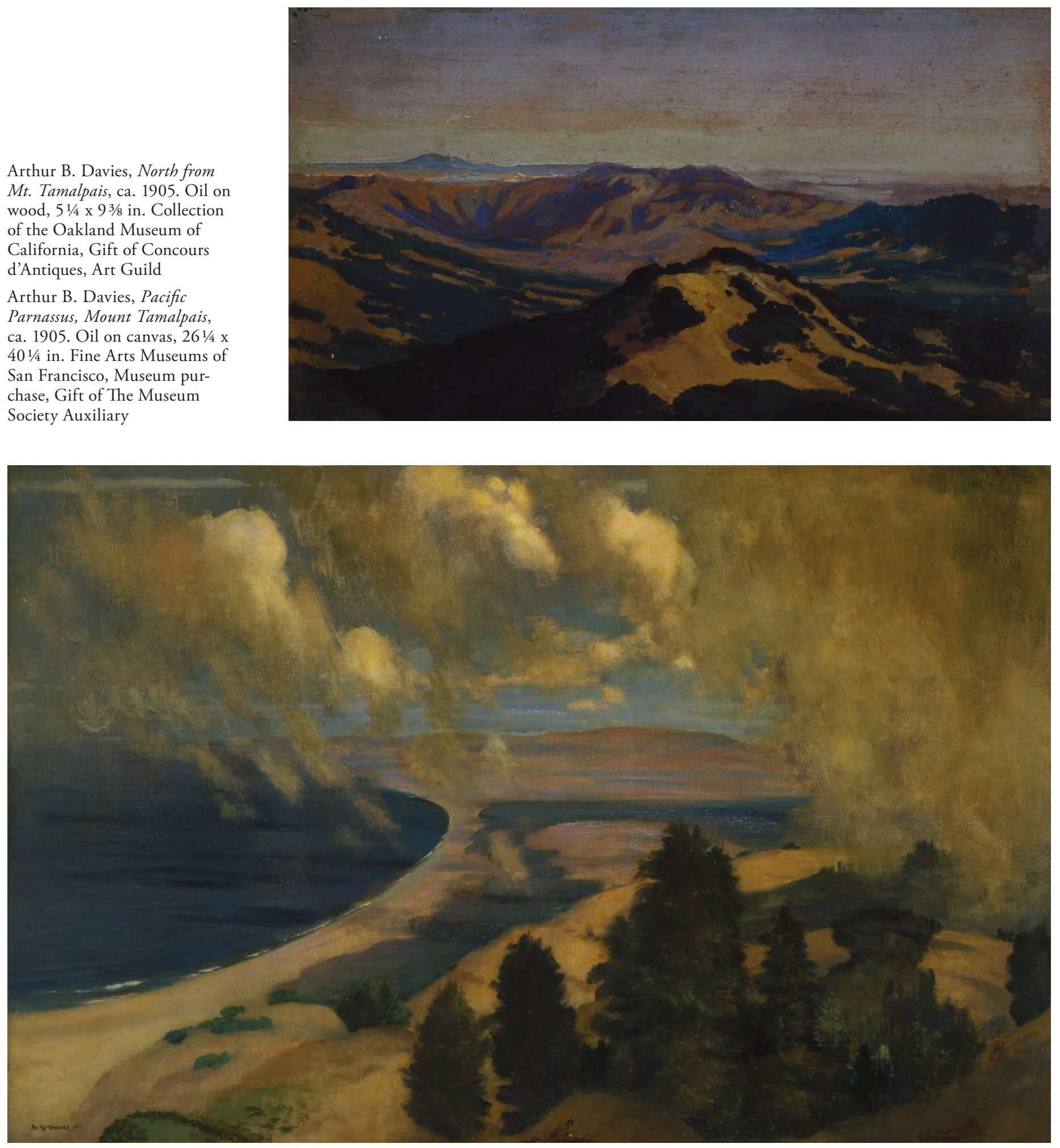


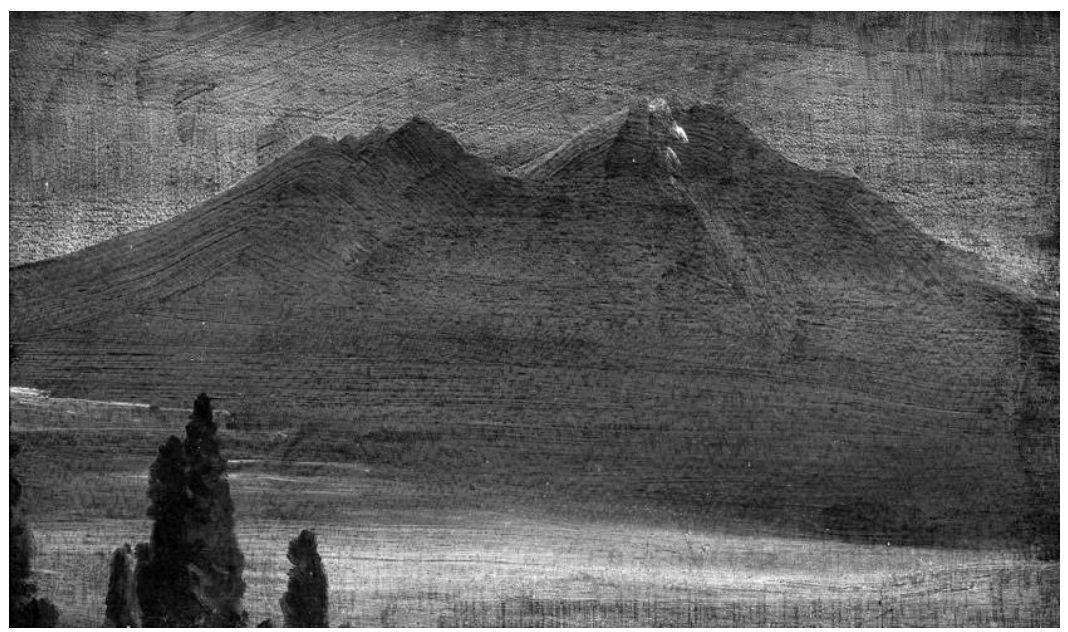

While the San Francisco view inscribed and donated to Martinez is unique among Davies's sketches, the Bay Area provided other scenic inspiration. Especially prominent in the region's hilly terrain is Mount Tamalpais, in Marin County, across the Golden Gate from the city. Like many artists of his day and later, Davies was drawn to the peak and the expansive view enjoyed from its heights. His sketch, North from Mt. Tamalpais (fig. 10), surveys the expansive Marin landscape. More than topography, however, in this work Davies's chief interest was the landscape's chromatic variety-russet hills, dark green foliage, lavender mist-producing "quirkily observed color notes," as one curator wrote, "freely brushed and boldly composed." 29

12 Arthur B. Davies, Mount Shasta, 1905. Oil on panel, $51 / 4 \times$ x 93/8 in. Private collection
Davies produced similar effects in a sketch from the summit of Mount Diablo, the highest peak in the East Bay region (Oakland Museum of California). Long a landmark for explorers in California, the Mount Diablo summit was established in 1851 as the official base point for California land surveys, and its base line and meridian lines continue to be used in many California real estate descriptions. Davies, however, was not interested in meridians or in real estate; instead, as he did at Tamalpais, he turned his attention to a chromatic study, registering the transition here from inky blue-blacks at the top of the composition to warm tans below. The view from such lofty perches continued to stir Davies's imagination even after his return to New York. Using the sketches and his keen memory, the artist reimagined the view of Stinson Beach, on the Marin County coastline, as the easel painting Pacific Parnassus, Mount Tamalpais (fig. 11), an early example of the continuing hold that California and the western landscape had on him.

Davies had arrived in San Francisco in late July and was still tarrying in the area in late August, enjoying its scenery and congenial company. But the artist was well into his fourmonth itinerary and had not yet reached Portland and the Lewis and Clark Centennial Exposition, the ostensible purpose of this long journey. By early September he left the Bay Area and headed northward and inland. In correspondence with his dealer, he noted stops in the Sacramento Valley country and another at Mount Shasta. ${ }^{30}$ However, feeling the pressures of time, he apparently had scant opportunity to paint at either site, and consequently there were only a few sketches made en route to Portland. ${ }^{31}$ Mount Shasta was an exception, its distinctive double-humped profile providing inspiration for at least two images. Enjoying the chromatic liberty that he had discovered in his Bay Area vignettes, Davies twice sketched Shasta-once with its pink slopes rising above greenery at the base, another time in deep blues, the mountain hovering like some monochrome mirage above a few treetops in the foreground (fig. 12).

In Portland he finally had the opportunity to view his paintings in the exposition's Fine Arts Museum, although finding his seven among the more than seven hundred works installed in multiple galleries must have been a challenge. ${ }^{32}$ Alas, his letters to his dealer include no references to the hunt or to his reaction on finding his work on view; neither did he discuss any of the other fine arts exhibits, nor other attractions at the exposition, which ranged from the Temple of Mirth to a Haunted Castle, numerous state and national buildings, and performers such as the One-legged Bicyclist or Trixie, the Educated Horse. What he did record were visits to private collectors in Portland and descriptions of their holdings. Opportunities for socializing were recounted in a name-dropping missive to 
Macbeth: "At Portland I saw Mr. Ladd, visited the house where I met Mrs. Ladd, who took me over to Mother Ladd's house, there I met Mrs. F. B. Pratt \& Mrs. Corbett (another Ladd)." After such a recitation of names and family ties, Davies graciously concluded, "All were extremely cordial as these westerners know how to be." 33

The highlight of Davies's Portland visit-even more than the Ladd clan and other cordial hosts - was a side trip to Mount Hood. He wrote with excitement to Macbeth, describing his "Three days on Mt. Hood with an unsuccessful expedition to the top, bad weather, soaked through by rain one day, and heavy snow Sunday with the opening of big crevasses above the 10,000 ft. snow fields. However a most exhilarating experience[,] one of my choicest." 34 Davies stayed there at the Cloud Cap Inn, the nation's oldest alpine lodge (built 1889), a tourist destination at that time reached only by stagecoach. Years later Davies still reveled in the memory of this adventure: "a thrilling experience. When I went by horse stageing [sic] from Hood River it was an unforgettable one." 35

The weather at Mount Hood was unfavorable for sketching, and soon Davies was headed farther north, to Seattle. From there in late September he began "making the turn homeward. With all too short a time left." He was headed toward Glacier Park, then to several more stops along the way ("two or three [days] at Emerald [Lake] \& the remaining time at Lake Louise") before taking the train to Montreal, then "home by night of Oct. 4th. My time limit." 36 The pace was rapid, and as a consequence, the northern leg of his trip was not frequently illustrated. His sketches made along the railway route were few but fresh, such as a view of the glacier on Mount Sir Donald in the Selkirk Range, one of the rare souvenirs of the trans-Canada passage (fig. 13).

Before leaving Seattle, the artist dispatched to Macbeth most of the oil sketches that would be used to create new easel paintings in the East. By early October, on his schedule, Davies was back in New York and reunited with his sketches-but not with his wife and sons. Rather, he returned to a new domestic arrangement, living in the city pseudonymously with his mistress, Edna Potter, as Mr. and Mrs. David Owen. The story of their relationship, which was unknown to nearly all of Davies's contemporaries, has now been made familiar by the artist's several biographers. ${ }^{37}$ Potter, a tall, lithe dancer, had begun modeling for Davies in 1902, and her graceful figure was the inspiration for many of the artist's nudes, largely dating from after the western trip, works by which he was best known to his contemporaries and to history.

The easel paintings that Davies produced in the immediate wake of his western sojourn were, however, different from those that had preceded his journey. The figures, generally female and usually nude, seemed more sensual than his earlier depictions of prim Victorian children, or young Madonnas, or subjects drawn from ancient mythology, like Psyche, exhibited at the Portland Exposition. Moreover, in Colorado and especially in California, landscape became newly important to the artist. The sketches were, with few exceptions, devoid of figures or evidence of human habitation, and so, too, were many of the most notable easel paintings they inspired.

Even though the western trip changed Davies's approach to landscape painting, his distinctive treatment of the genre had been noted earlier. For instance, reviews of his Boston show in February 1905 lauded "[h]is pictures [that] are of a visionary caste, and are memories rather than direct representations of nature."38 Though "visionary," Davies's landscapes were based on his "conscientious interrogation of nature" - as in the oil sketches - a focus that the critic Royal Cortissoz would later assert "was at the bottom of his art." 39 Memories of the West percolated in Davies's imagination and prompted a new emphasis on landscape, with results that were sometimes even more visionary than his earlier work. In Canyon Undertones (fig. 14), a large canvas inspired 
13 Arthur B. Davies, Mount Sir Donald Glacier, 1905 . Oil on panel, $51 \frac{1}{4} \times 9 \frac{1}{2}$ in. Private collection

14 Arthur B. Davies, Canyon Undertones, ca. 1905-6. Oil on canvas, 25 x 39 in. Private collection
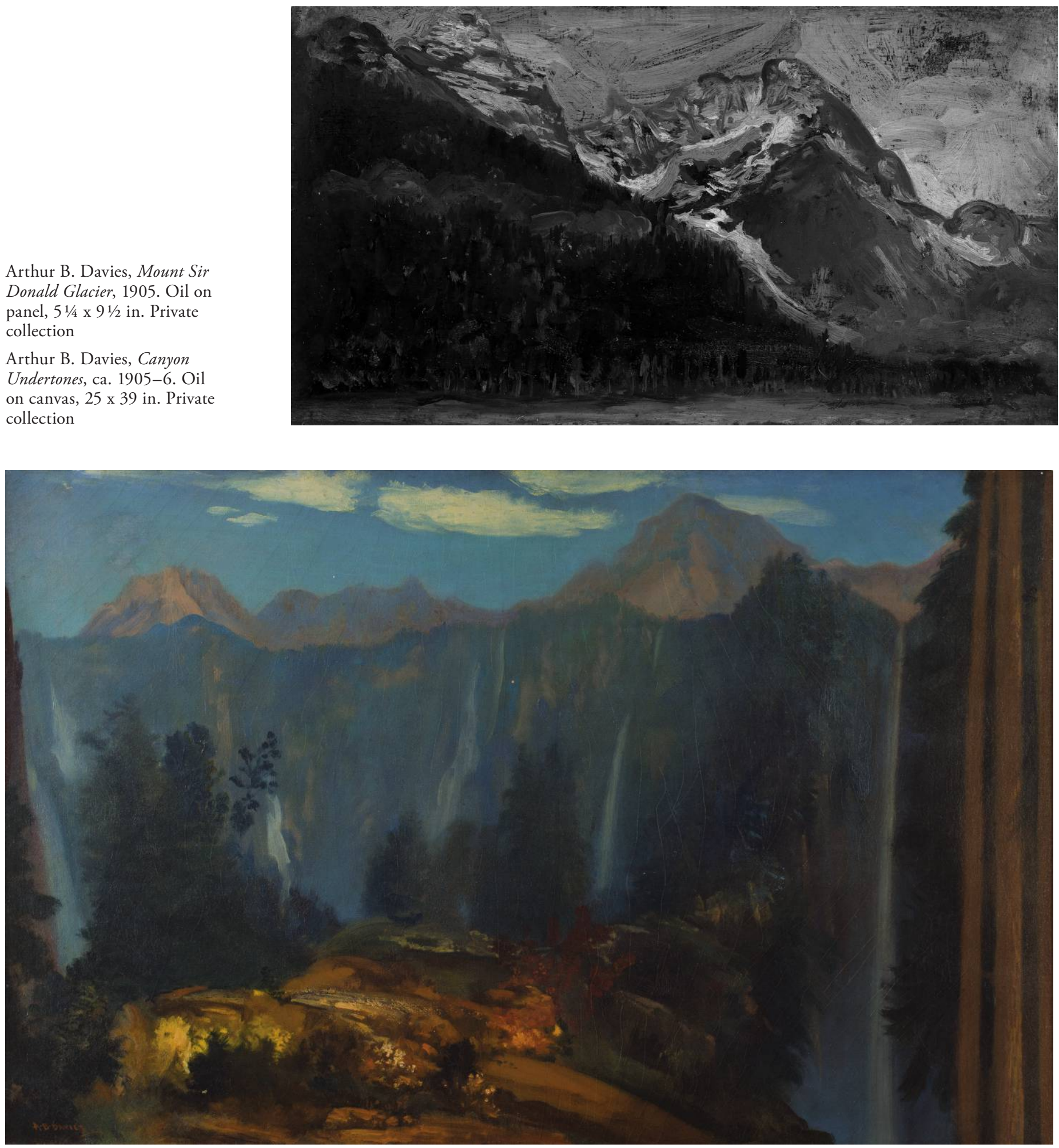
15 Arthur B. Davies, Leda and the Dioscuri, ca. 1905. Oil on canvas, $26 \times 40$ in. Spencer Museum of Art, University of Kansas, Museum purchase, Peter T. Bohan Art Acquisition Fund, 2014.0138

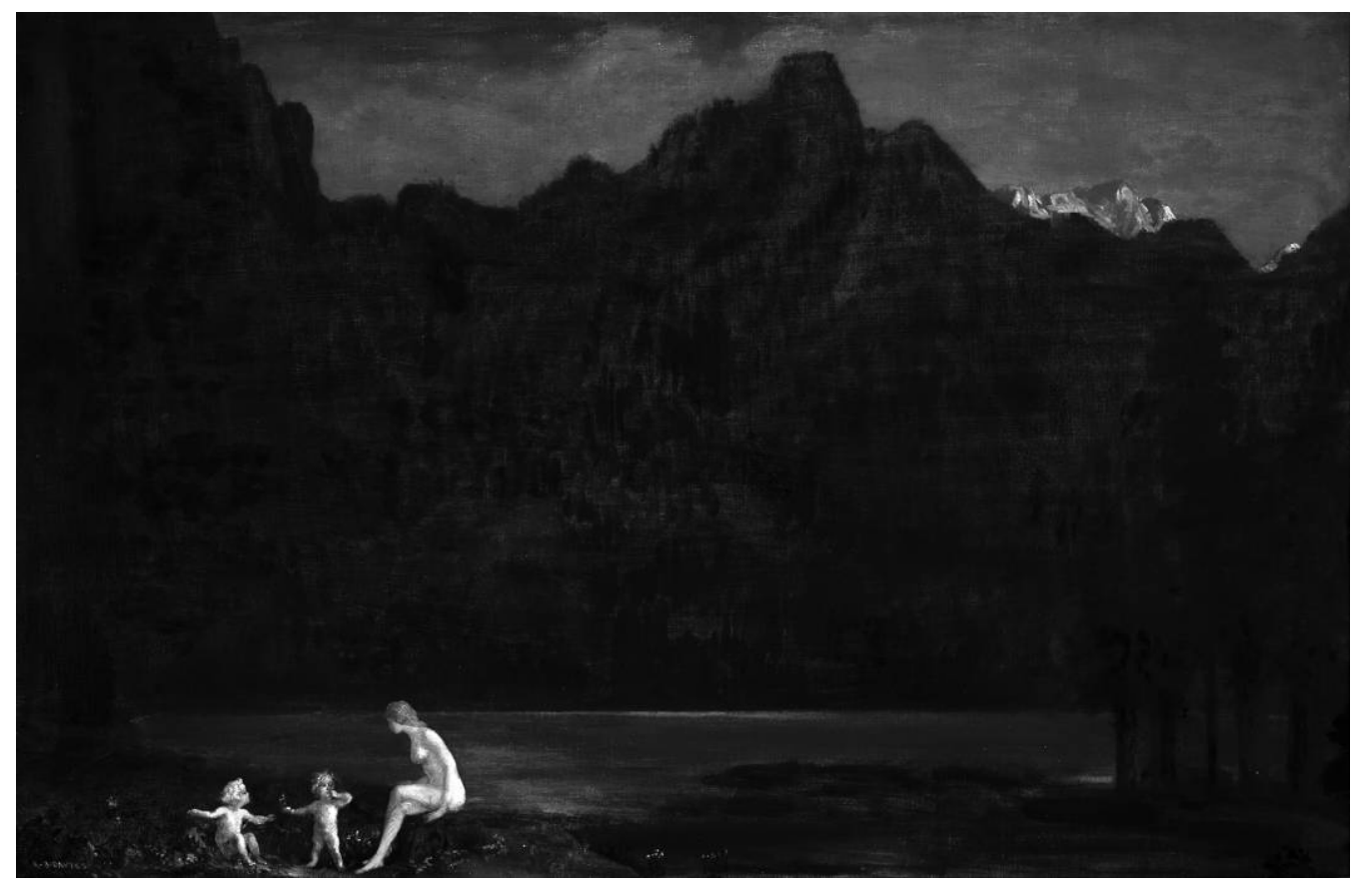

by the Sierra Nevada country, the foreground canyon floor is ringed by steep cliffs down which multiple cascades plummet. The cliffs-and-waterfalls motif appeared as well in Many Waters (ca. 1905, Phillips Collection), one of Davies's best-known landscapes, with the cascades further multiplied, as if he was seeking to include all of Yosemite's famous falls in one hydraulic fantasy. The view, with the Merced River flowing in the foreground, is purely imaginary, for the dozen cascades depicted are nowhere visible from a single vantage point in the park.

The jagged profile of the Sierra figures prominently in the backgrounds of numerous landscape paintings executed following Davies's return to New York. In Before Sunrise (1905, ex-Corcoran Gallery of Art), the warm glow of a new day rises above the dark plane of jagged peaks; in this work, as in another Sierra subject, Horizons (ca. 1906, Washington County Museum of Fine Arts), the view is punctuated by the verticals of tall pines, a compositional device familiar from some of his Lake Tahoe sketches. The elongated horizontal format (18 by 40 inches) of these pictures was used in a number of western views and suggests the panoramic landscape that Davies enjoyed in California. In Leda and the Dioscuri (fig. 15), lofty mountains provide a backdrop for a diminutive Castor and Pollux and their mother, the trio improbably relocated from the ancient Greco-Roman world to a Sierran lakeside, giving new meaning to notions of the "mythic West." Davies also introduced tiny figures into his large canvas The Lure of the Chase (fig. 16). In its lower margin, dogs chase, deer flee, and figures gambol among the pines. While their purpose may only have been to provide a sense of scale for the landscape's vastness, their size and placement tempt comparison to Washington Allston's romantic Diana on a Chase (1805, Harvard Art Museums/Fogg Museum), with its small mythological figures similarly transplanted to the corner of an expansive mountain view.

Davies likely painted his view of Stinson Beach from sketches made nearby. He titled the work Pacific Parnassus, Mount Tamalpais (see fig. 11), a reference to the 


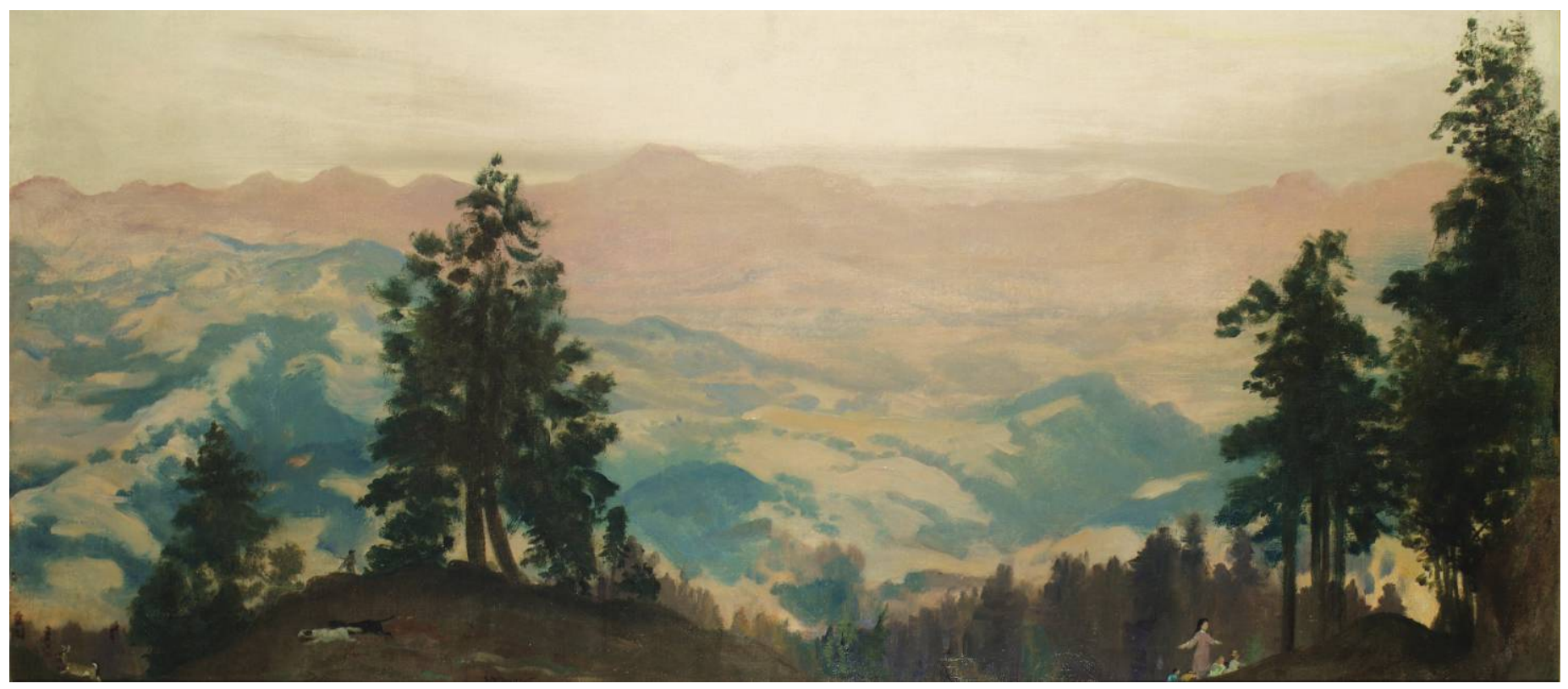

16 Arthur B. Davies, The Lure of the Chase, 1905. Oil on canvas, $18 \times 40$ in. Huntington Art Collections, San Marino, Calif., Purchased with funds from the Art Collectors' Council, Margery and Maurice Katz, and the Virginia Steele Scott Foundation (C) Courtesy of the Huntington Art Collections, San Marino, Calif. mountain sacred to Apollo and home to the Muses, the locus of creativity now relocated from Greek mythology to the California coast. Unlike Raphael's famed Vatican fresco of Parnassus, in which the artist looked up to Apollo and his Muses, Davies assumes the lofty position of the god and looks outward, surveying the arc of blue Pacific and sandy shoreline beneath the moist clouds passing overhead. In the lower right corner of the composition Davies quickly and lightly sketched three small nudes playing on the grassy slope. Easily overlooked in a casual glance, their presence signals California as the new Arcadia, its muses beckoning from a golden shore.

In addition to mountains and Pacific shorelines, forests left their impression on the artist, particularly the giant California redwoods. The shafts of their trunks recur in numerous studio paintings, occasionally singly, more often in groups suggestive of the famous groves. In the woods, human figures, especially female nudes, assume larger proportions and more prominent roles. Posed before a distant view in Hills of the Sierras (ca. 1909-10, Frye Art Museum), five nudes seem at home in nature; the upstretched pose of one standing figure rhymes with the trunk of the tree beside her, an alignment similar to contemporaneous images by the California photographer Anne Brigman. In Davies's On the Cliffs (ca. 1905, Smithsonian American Art Museum), another group contemplates a redwood; the seated pair at left seems transfixed by its height, while the trio at the right embraces the trunk as if to take in its girth.

More often, in sketches and in subsequent easel paintings, multiple tree trunks suggest the density of the ancient redwood groves that Davies enjoyed in California. Later paintings of such subjects were often populated with creatures, real or imaginary. In The Nearer Forest (fig. 17), beauty and beast are linked as female nudes escort a pale horse into the grove's interior-perhaps a precursor to the fantastic white creatures that appeared the next year in Davies's most famous work, Unicorns (Legend-Sea Calm) (ca. 1906, Metropolitan Museum of Art). In Redwoods (ca. 1905, Santa Barbara Museum of Art), a group of female nudes and scantily clad men crowd the grove. Several muscular males wield axes, as if threatening the giant 


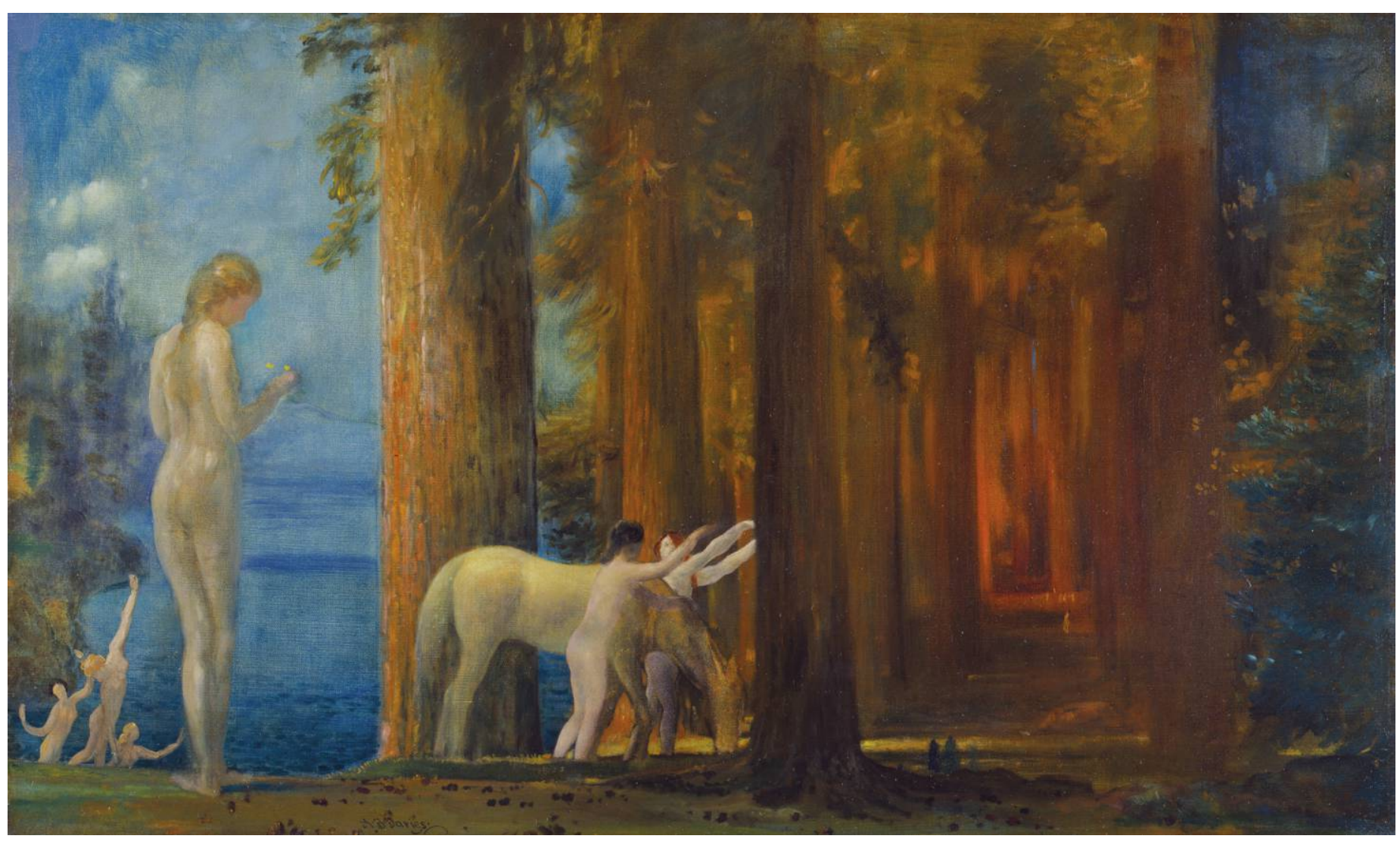

17 Arthur B. Davies, The Nearer Forest, 1905. Oil on canvas, $18 \mathrm{x}$ 30 in. Myron Kunin Collection of American Art, Minneapolis, Minn. trees; a heap of bodies lies on the forest floor, seemingly mourned by a kneeling figure, while a female nude floats gracefully above. A celebration of nature and sensuality? A lament over death or deforestation? Or some more personal narrative? Davies's intent here, as in so many of his works, is left ambiguous.

A Mighty Forest-Maenads (fig. 18) seems clearer in its mood and meaning. In a redwood grove, a reddened troupe of female nudes dances athletically, their slender figures and graceful poses suggesting the inspiration of Davies's model and mistress, the modern dancer Edna Potter. Visions of Potter appear in many of the artist's post-California works, with A Mighty Forest being one of the most striking. Also reappearing is his interest in classical mythology, suggested by the maenads, the female followers of Dionysus who were often excited by their leader into a state of ecstatic frenzy. The single figure who bursts forward to center stage, her arms upraised, is the embodiment of sensual energy_Edna among the redwoods, a truly bohemian grove. She animates her companions at left and right and charges the picture-and the artist's life-with sensual, indeed erotic, power.

Visions of mountains and redwoods and of Potter continued to stir Davies's creativity years after his return from the West. In Crescendo (1910, Whitney Museum of American Art), seven nudes strike poses before a profile of high and craggy peaks; nine figures do the same in Rhythms (ca. 1910, Milwaukee Art Museum), as does a troupe of twelve in Moral Law-Line of Mountains (ca. 1911, Virginia Museum of Fine Arts). In Silence, Waterfall and Forest (fig. 19), Davies returns in his imagination to Yosemite, positioning his figure against a stand of redwoods, listening to the falls. The feminine subject, the mysterious stillness of 


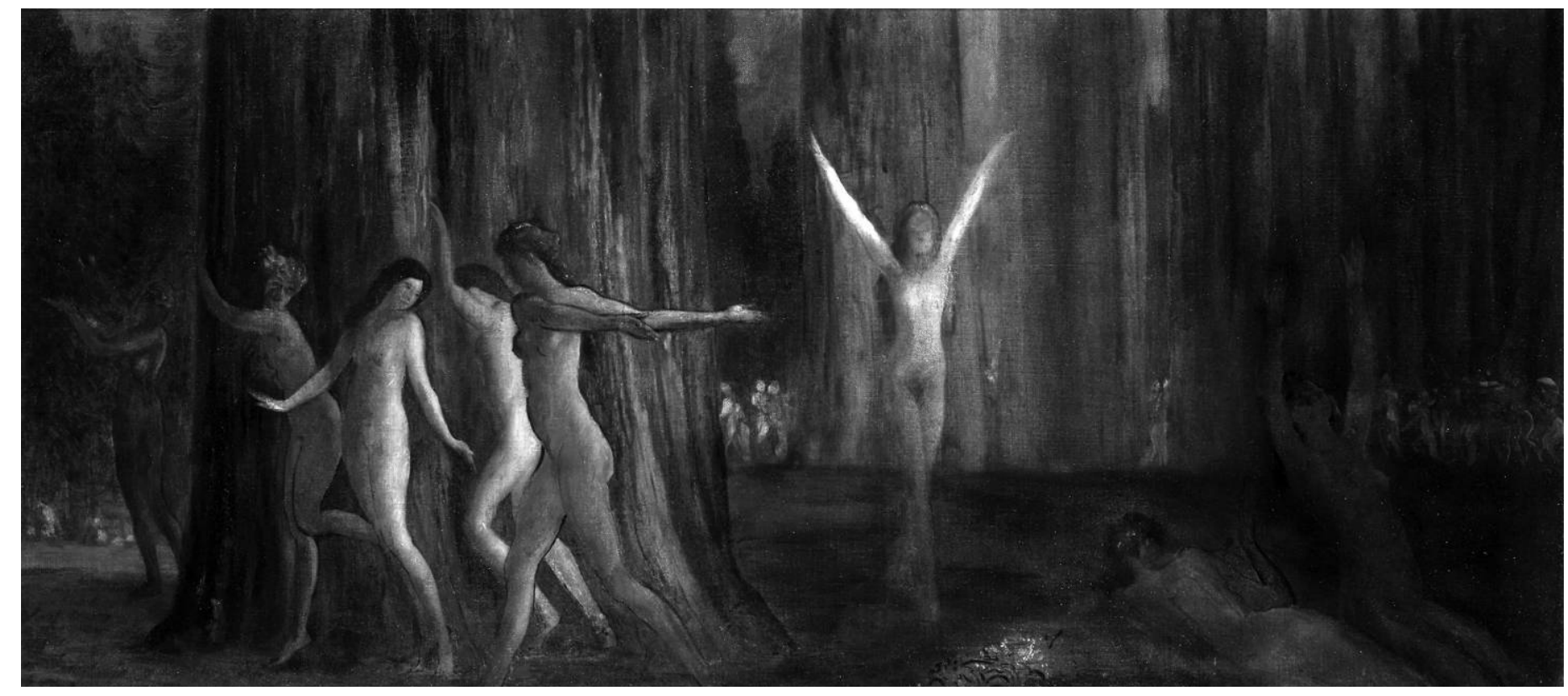

18 Arthur B. Davies, A Mighty Forest-Maenads, ca. 1905. Oil on canvas, 18 x 40 in. Image courtesy of Doyle New York

19 Arthur B. Davies, Silence, Waterfall and Forest, n.d. Oil on canvas, $293 / 4 \times 17 \frac{1}{2} \mathrm{in}$. The Dayton Art Institute, Gift of Mr. C. N. Bliss, 1943.2. Photo courtesy of The Dayton Art Institute

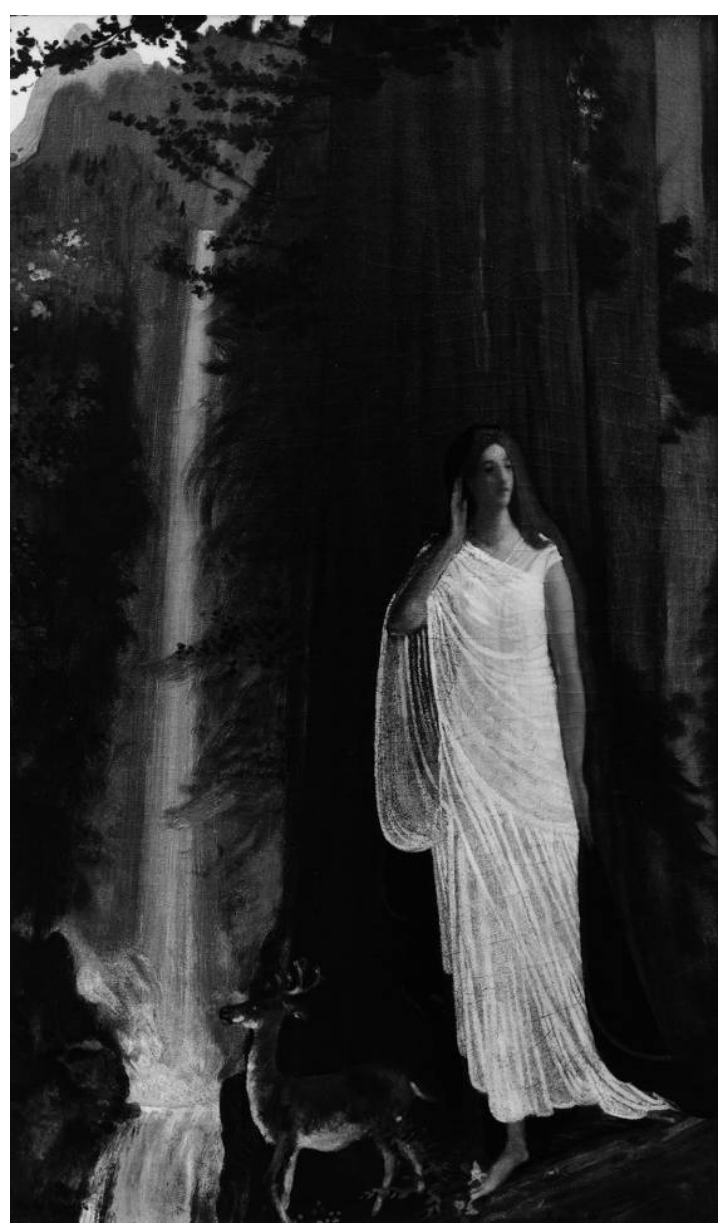

the scene, and its auditory theme all suggest the legacy of Odilon Redon and late nineteenth-century symbolist iconography, now relocated to the American West.

By the time he painted Silence, Davies was already a veteran of the legendary exhibition of The Eight presented at Macbeth's gallery in February 1908. The show was a landmark in the development of urban realism in American art, a gathering in whose company Davies's six imaginative works, including at least two paintings inspired by California, might have seemed out of place. ${ }^{40}$ Davies's seniority, however, and his sympathy for the moderns were accepted by his fellow exhibitors. By 1912 those same attributes led to his crucial role, as president of the Association of American Painters and Sculptors, in organizing the monumental Armory Show that debuted the following year. In his foundational chronicle of the Armory Show, Milton Brown asserted, "Without [Davies] it never would have happened." 41 
20 Arthur B. Davies, Listening to the Water Ousel, ca. 1915. Oil on canvas, mounted on panel, $13 \mathrm{x}$ 11 in. Collection of the McNay Art Museum, Bequest of Mrs. Jerry Lawson

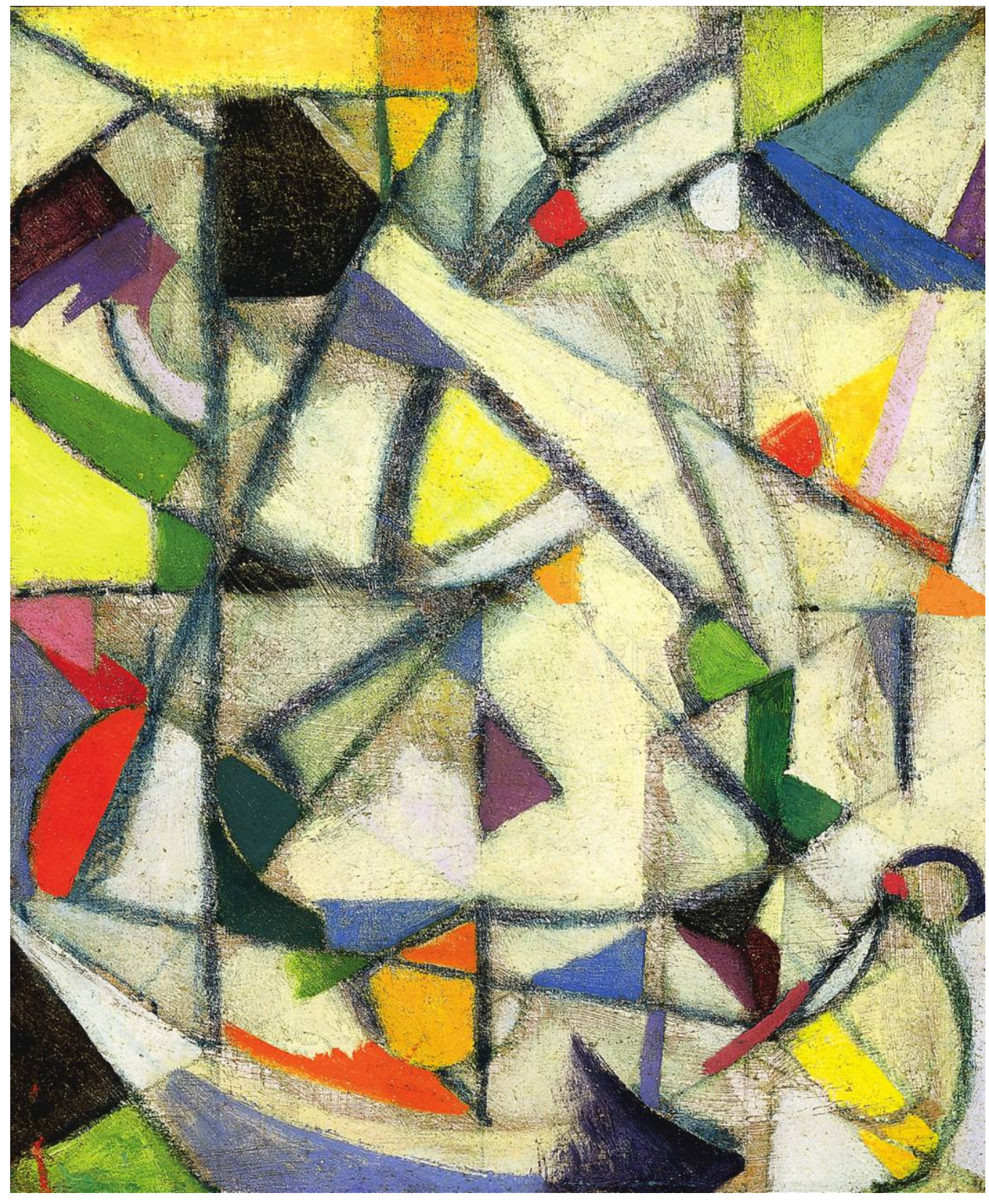

That exhibition is often credited with introducing a broad American audience to advanced European modernism; it also transformed Davies's art, at least momentarily, into abstract designs of cubist fracture, before he reverted to figurative subjects in his later years. Yet even while briefly in the cubist thrall, Davies's western adventure of a decade earlier was still on his mind. About 1915 he painted an abstract design with the curious title Listening to the Water Ousel (fig. 20). The ouzel is a western bird found along mountain streams in Pacific ranges from Alaska to Mexico and east to the Rocky Mountains. In the Sierra John Muir was particularly fond of the little bird, which he called "the mountain streams' own darling, the hummingbird of blooming waters. ... Among all the mountain birds, none has cheered me so much in my lonely wanderings." Muir delighted in "the spontaneous, irrepressible 
21 Arthur B. Davies, Listening to the Ouzel, 1905. Oil on canvas, $141 / 4$ x $18 \frac{1}{2}$ in. Courtesy of Joel B. Garzoli Fine Art, San Francisco, Calif.

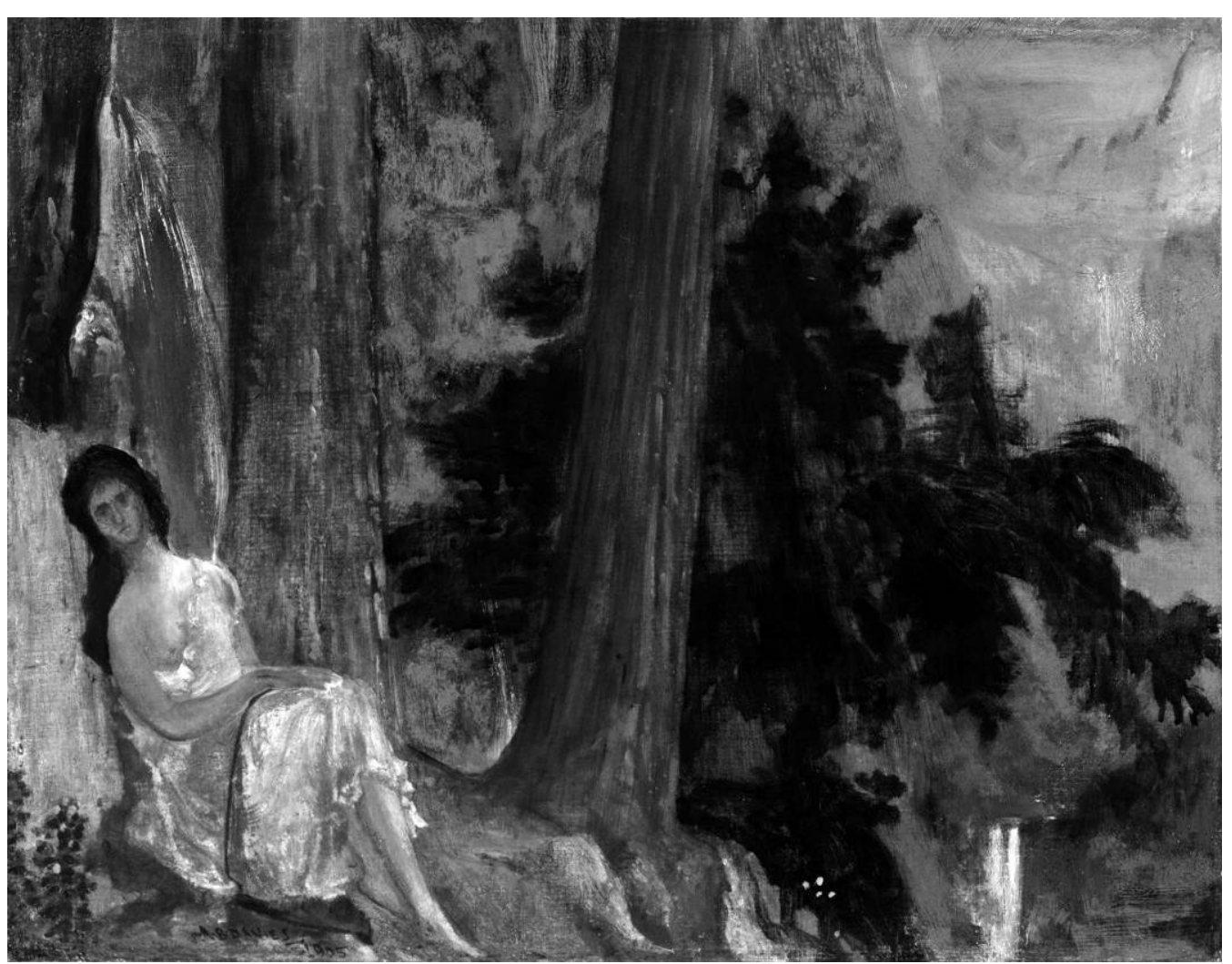

gladness of the Ouzel," which he watched along the Merced River, an area where Davies enjoyed sketching. 42

Like Muir and many others, naturalists and tourists alike, Davies was drawn to the brave little waterbird. While in California or, more likely, shortly after his return, he painted a small canvas depicting a seated woman, Listening to the Ouzel (fig. 21). But more than simply the song and the antics of a western waterbird, the design of about 1915 suggests the lingering hold of an enchanted time and place on the artist's imagination.

It is notable that in Virgil Barker's introduction to a 1924 catalogue of Davies's works in diverse media, many of them figurative in design, the author located Davies's special inspiration in nature and the landscape. Indeed, without specifically naming it, Barker suggested its source in the artist's long-ago, singular trip to the American West. "In Davies-Land are to be found long coast lines and majestic mountain ranges, valleys of dew-pure charm, trees rising tall and solemn into serene heights of sky, legendary beasts and noble beings. ... These pictures," Barker advised, "ask, not an optical recognition of familiar details, but an emotional comprehension of mood. The appreciation of them is . . . an activity of the mind which has the keen pulsation of temperateness." He concluded, "The paintings of Arthur B. Davies constitute this time's most explicit appeal to the imagination. Therein lies their measure of greatness." 43 It was an imagination, and a greatness, fueled by the discoveries of his western sojourn during the summer of 1905 . 


\section{Notes}

Numerous collectors, dealers, and museum colleagues made works available to me over the long gestation of this project, and their kindnesses are much appreciated. I am indebted as well to my research assistants Clair Robertson, Mindy Besaw, Samantha Lyons, and Meaghan Walsh for their expert help at multiple stages in the essay's preparation, and to my colleague Mark Olson for his assistance with images. My research has been generously supported by the Hall Family Foundation through the Kansas University Endowment Association, for which I am extremely grateful.

1 Arthur I. Street, "Another 'Go West' Period," Sunset 14, no. 3 (January 1905): 205-17.

2 Henry David Thoreau, "Walking," Atlantic Monthly 9, no. 56 (June 1862): 662.

3 The attraction to the Lewis and Clark Exposition may have been further enhanced by family ties. The artist's wife, Dr. Virginia Meriwether Davies, was related to the explorer Meriwether Lewis, whose feat was being celebrated at Portland. Dr. Davies, however, did not accompany the artist on his trip to the West.

4 As Davies rarely dated his works, determining their historical sequence has always been a challenge, reliant on exhibition dates, sales records, reproductions, and similar extrinsic information. In the catalogue for the memorial exhibition at the Metropolitan Museum of Art, New York, in 1930, Davies's widow provided an extensive listing of paintings, some with owner and (her) dates included. Over time, however, this inventory has proven incomplete and in many instances inaccurate. Nonetheless, it is the basis for the dates provided in this paragraph, each of which might prudently be considered circa. For all, the terminus ante quem would be the year of the Portland exhibition: 1905.

5 Eleanor Jones Harvey, The Painted Sketch: American Impressions from Nature, 1830-1880 (Dallas: Dallas Museum of Art in association with Harry N. Abrams, 1998), 20; and "Our Artists and Their Whereabouts," Cosmopolitan Art Journal 2 (September 1858): 209.
6 Henry T. Tuckerman, Book of the Artists: American Artist Life. . . . (New York: G. P. Putnam and Son, 1867), 389.

7 Quoted in Frederic Newlin Price, "The Etchings and Lithographs of Arthur B. Davies," Prints 1, no. 1 (November 1930): 8, quoted in Bennard B. Perlman, The Lives, Loves, and Art of Arthur B. Davies (Albany: State Univ. of New York Press, 1999), 146.

8 Davies to William Macbeth, August 1898, Macbeth Gallery Records, 18381968, bulk, 1892-1953, Archives of American Art, Smithsonian Institution (hereafter AAA), reel NMc6, frames 305, 251, quoted in Perlman, Lives, Loves, and Art, 105, 106.

9 Davies to William Macbeth, June 18, 1905, Macbeth Records, AAA, reel NMc6, frames 315-16.

10 Davies to William Macbeth, September 21, 1905, Macbeth Records, AAA, reel NMc6, frame 320 .

11 Unidentified clipping ("American Art: A Partial Glimpse”), ca. 1905, Ferargil Galleries Records, circa 1900-1963, AAA, reel 1028, frame 766 .

12 Davies to Macbeth, June 18, 1905 , frame 316.

13 Ibid., frames 315, 316

14 Davies to William Macbeth, July 18, 1905, Macbeth Records, AAA, reel NMc6, frames 317-18, at 318.

15 Ibid., frames 317-18.

16 Perlman, Lives, Loves, and Art, 149

17 S. H. Smith, "In Bret Harte's Country," Sunset 15, no. 1 (May 1905): 33.

18 John Muir, "The Treasures of the Yosemite," Century Magazine 40, no. 4 (August 1890): 483-500; and "Features of the Proposed Yosemite National Park," Century Magazine 40, no. 5 (September 1890): 656-67.

19 Marsden Hartley, "The Poetry of Arthur B. Davies' Art," Touchstone and the American Art Student Magazine 6, no. 5 (February 1920): 278. Reprinted as "Arthur B. Davies," in Hartley, Adventures in the Arts: Informal Chapters on Painters, Vaudeville and Poets (New York: Boni and Liveright, 1921), 82.

20 Elsie Whitaker Martinez, interview by Franklin D. Walker and Willa Klug Baum, in "San Francisco Bay Area Writers and Artists," Univ. of California
Regional Oral History Office, typescript, 106, Bancroft Library, Univ. of California, Berkeley.

21 Mary Austin, Earth Horizon: Autobiography (Boston: Houghton Mifflin Co., 1932), 297

22 One drawing, mistitled and misdated as Mission Dolores, San Francisco, 1913, is in the collection of the National Gallery of Art (acc. no. 1984.7.32); another is in a Davies sketchbook at the Oakland Museum of California (acc. no. 68.66).

23 Numerous other objets d'art are pictured or listed in inventories in the Vickery, Atkins \& Torrey Records, ranging from Della Robbia religious sculpture to Frederick MacMonnies's Pan of Rohaillon. Vickery, Atkins \& Torrey Records, [undated] and 19011930, owned by California Historical Society, microfilmed by AAA, reel 1080 .

24 John Davis Hatch to Paul Mills, February 1966, letter, Oakland Museum curatorial files. Hatch owned two drawings by Davies, including one reportedly of Mission San Luis Obispo. He also owned a small sketchbook containing five more California drawings. Davies had given the sketchbook to Frederick Torrey in 1905; in 1939 Torrey's daughter gave it to Hatch, who in turn donated it to the Oakland Museum. Information from curatorial files, Oakland Museum of California.

25 On its verso the panel bears a dedication in the artist's hand, "To Martinez-from A B Davies Aug 21, 1905."

26 There were parallels in their career trajectories as well. Both (like many of their era) had begun as illustrators. In August 1905 Sunset magazine (Nonette V. McGlashan, "The Legend of Tahoe," Sunset 14, no. 4 [August 1905]: 375-78) published Martinez's illustrations for "The Legend of Tahoe," an area that Davies had illustrated in 1890 and that more recently had inspired him while en route to San Francisco. In their subsequent works as well, there were stylistic affinities between the soft focus and tonal qualities of many of Davies's paintings, especially from his early period, and Martinez's landscapes and figurative compositions. 
27 Other subjects commissioned by Davies included the poet and playwright George Sterling, the humorist and illustrator Gelett Burgess, the socialist author Anna Strunsky, and the Tasmanian-born watercolorist Francis McComas. Janet B. Dominik, "Xavier Martinez," in Plein Air Painters of California: The North, ed. Ruth Lily Westphal (Irvine, Calif.: Westphal Publishing, 1986), 101, 196n10.

28 Elsie Whitaker Martinez interview, typescript, 88 .

29 Nancy Boas and Marc Simpson, "Pastoral Visions at Continent's End: Paintings of the Bay Area 1890 to 1930," in Steven A. Nash, Facing Eden: 100 Years of Landscape Art in the Bay Area (San Francisco: Fine Arts Museums of San Francisco, 1995), 43. In one pencil sketch, describing a coastal landscape, Davies similarly made note of colors, but verbally, not in paint; he inscribed the page with "spring green," "olive green," "grey indigo blue," and "violet" (Sketchbook, Oakland Museum, acc. no. 68.66).

30 Davies to William Macbeth, September 21, 1905, Macbeth Records, AAA, reel NMc6, frames 319-21.

31 According to one source, Davies "in at least one instance, around 1908 [sic] ... painted an unusual view of just Shastina and the meadows below (this view, quite ordinary, was perhaps a conscious attempt, in keeping with his views on the philosophy of art, to not paint a more traditional view of the mountain)." The same source mentions other paintings by Davies of Mount Shasta, but without illustration or identification. "East Coast Artists: 1870s-1920s," in The Significance of Mount Shasta as a Visual Resource in 19th and Early 20th Century California Art, accessed May 28, 2010, http:// www.siskiyous.edu/shasta/art/eas.htm.

32 Davies was represented by Dryad Hill, Forest Chorus, Autumn Flame and Passion, The Wish, The Source, and Newfoundland Coast (all loaned by William Macbeth), plus Psyche (loaned by Mr. F. B. Pratt, Brooklyn). Catalogue of the Fine Arts Exhibit of the Lewis and Clark Centennial Exposition (Portland, Oreg.: Albert Hess \& Co., 1905), 16, $40,45,65$.

33 Davies to Macbeth, September 21, 1905, frames 319-20.

34 Ibid., frame 320.

35 Davies to Sally Lewis, March 27, 1923, Arthur B. Davies Letters to Sally Lewis, 1919-1923, AAA, reel 2803, frame 252.

36 Davies to Macbeth, September 21, 1905, frame 319.

37 See, for instance, Brooks Wright, The Artist and the Unicorn: The Lives of
Arthur B. Davies (1862-1928) (New City, N.Y.: Historical Society of Rockland County, 1978); and Perlman, Lives, Loves, and Art, each notable for the plural nouns in its title.

38 "Art and Artists: Exhibition of Oil Paintings by Arthur B. Davies," Boston Sunday Globe, February 26, 1905, 35.

39 Royal Cortissoz quoted in "Davies the Mystic," Literary Digest, January 19, 1929, 20.

40 Davies included Many Waters and A Mighty Forest-Maenads in The Eight exhibition, the former inspired by Yosemite's cascades, the latter by the redwood groves. Perlman, Lives, Loves, and Art, 163.

41 Milton W. Brown, The Story of the Armory Show (New York: Abbeville, 1988), 82.

42 John Muir, The Mountains of California (1894; New York: Modern Library, 2001), 201, 204. Muir was so enchanted by the bird that he devoted an entire chapter of his book to the subject (chap. 13, "The Water-Ouzel").

43 Virgil Barker, introduction to $A n$ Exhibition of Paintings, Drawings and Water Colors by Arthur B. Davies (Pittsburgh: Carnegie Institute, 1924), n.p. 